\section{Discoversys \\ Published by DiscoverSys \\ Utilization of the smoking cessation clinic at Public Health Centre 1 North Denpasar: A qualitative study}

\author{
Sri Idayani, ${ }^{1 *}$ Putu Ayu Indrayathi, ${ }^{2}$ Dyah Pradnyaparamita Duarsa, ${ }^{2}$ Dinar Lubis ${ }^{2}$
}

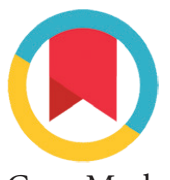

CrossMark

\section{ABSTRACT}

Background and purpose: The incidence of morbidity and mortality due to tobacco use is very high. There are several strategies to help smokers quit, one of which is counseling to stop smoking in a clinic setting. The purpose of this study was to explore in depth the utilization of smoking cessation clinics at a Public Health Centre (PHC).

Methods: A qualitative study through in-depth interviews was conducted with 14 informants who had been provided with a counseling at a smoking cessation clinic, consisting of five informants who had quit smoking and nine informants who were still smoking. Triangulation of data was carried out by conducting in-depth interviews with the head of PHC and one counselor on duty at the smoking cessation clinic. The information collected includes the utilization of the clinic, strategy of PHC in recruiting patients, knowledge about smoking cessation and the benefits of attending counseling. Data collection was carried out at the home of each informant during March-April 2018. The results of the interviews were analyzed thematically after a verbatim transcription being conducted. The data presented in a narrative to provide an in-depth description of the utilization of smoking cessation clinics in a PHC.

Results: The results of interviews with PHC staff showed that in order to increase the utilization of the smoking cessation clinic, the services are integrated into the general polyclinic. Interviews with informants who have not stopped smoking indicate that to improve the utilization of the clinic, promotion and service variations are needed and not only focus on counseling. Interviews with informants who have stopped smoking show that counseling at the clinic can increase their willingness to stop smoking.

Conclusion: To improve the utilization of smoking cessation clinics, in addition to integrating services into the general polyclinic, promotion and variations in services are also required.
${ }^{1}$ School of Laboratory Technologist, Wira Medika Health Institute; ${ }^{2}$ Department of Public Health and Preventive Medicine, Faculty of Medicine, Udayana University

*Correspondence to: Sri ldayani, School of Laboratory Technologist, Wira Medika Health Institute

iid_wika@yahoo.com

Keywords: utilization, smoking cessation clinic, public health centre, qualitative Cite This Article: Idayani, S., Indrayathi, P.A., Duarsa, D.P., Lubis, D. 2018. Utilization of the smoking cessation clinic at Public Health Centre 1 North Denpasar: A qualitative study. Public Health and Preventive Medicine Archive 6(2): 148-153. D0I:10.15562/phpma.v6i2.183

\section{INTRODUCTION}

Smoking is one of the major risk factors for non-communicable diseases such as cancer, cardiovascular disease, bronchitis, emphysema/ chronic obstructive pulmonary diseases (COPD) and pneumonia. ${ }^{1}$ The proportion of smokers is high in several developing countries, including in Indonesia. The 2018 Indonesia Basic Health Research or Riset Kesehatan Dasar (Riskesdas) shows that the proportion of daily and occasional smokers was $29.3 \%$ in 2013 , decreasing to $28.8 \%$ in 2018, and in Bali Province, the proportion was $22.4 \%$ in 2013 and $23.5 \%$ in $2018 .^{2}$

A study on the utilization of smoking cessation clinics in Yogyakarta that adopted the PRECEDEPROCEED Model by Lawrence Green showed that the utilization of smoking cessation clinics was influenced by predisposing factors such as patient motivation and perception on quitting smoking and reinforcing factors in the form of social pressure on intention to use smoking cessation clinics. In addition, enabling factors of the utilization of smoking cessation clinics included the lack of space, supporting facilities and human resources. ${ }^{3}$
The Government of Bali Province, through the health office, has made various efforts to reduce the number of smokers, one of which is by establishing a smoking cessation clinic in primary health care and referral facilities. The Denpasar City Government has four smoking cessation clinics available in public health centers (PHCs) which one of them is at PHC-1 North Denpasar. The cumulative number of patients utilizing the smoking cessation clinic in PHC-1 North Denpasar from 2013 to 2017 was 573 persons. According to the PHC report, there were only three patients who managed to stop smoking. ${ }^{4}$ This data shows that the success of smoking cessation clinics in PHC-1 North Denpasar remains low. This study aims to explore in depth the utilization of smoking cessation clinic in PHC-1 North Denpasar. An in-depth study on the use of smoking cessation clinics would inform the efforts to improve the quality of services in PHC-1 North Denpasar.

\section{METHODS}

This study employed a qualitative design through in-depth interviews. Data collection was conducted 
from March to April 2018 at the smoking cessation clinic at PHC-1 North Denpasar. PHC-1 North Denpasar was selected to be the study site as the PHC has the highest number of referrals from the general polyclinic to the smoking cessation clinic.

Interviews were conducted by the first author using in-depth interview guides which incorporated the aspects of the PRECEDE-PROCEED Model..$^{5}$ The information collected includes the utilization of the clinic, strategy of $\mathrm{PHC}$ in recruiting patients, knowledge about smoking cessation and the benefits of attending counseling. The number of informants was determined by the information saturation which means that the recruitment of informants was terminated if no new meaningful information was obtained during the in-depth interview. ${ }^{6}$ The informants of this study were 14 patients who have visited the smoking cessation clinic at PHC-1 North Denpasar, included nine patients who were active smokers and five patients who had stopped smoking. Data was validated by carrying out a source triangulation through in-depth interviews with one health worker and the head of PHC. The interview guide for the health worker and the head of PHC was similar to the interview guides used for patients with some adjustments based on the required information.

The data analysis was conducted thematically to identify the main themes that describe the utilization of the smoking cessation clinic in PHC-1 North Denpasar. The first step of data analysis was to play the recording of the in-depth interviews iteratively. The second step was transcribing, coding and grouping the codes into themes and sub-themes. The final step was reviewing, modifying and developing the preliminary themes. In this step, all data associated with each theme was identified and gathered together to finally define the main themes. This study has been approved by the Ethic Committee of Faculty of Medicine, Udayana University/Sanglah General Hospital on 1 March 2018.

\section{RESULTS AND DISCUSSION}

\section{Informant Characteristics}

Informant characteristics are presented in Table 1. Informants consisted of 14 patients who have visited the smoking cessation clinic at PHC-1 North Denpasar, included nine patients who were active smokers and five patients who had stopped smoking, one smoking cessation counselor and the head of PHC. All patients participated in this study were males and aged with the range from 23 to 70 years old. The patients' education varied from elementary to bachelor graduates and mostly were private employees.
There were three themes emerged from the data analysis regarding the utilization of smoking cessation clinics, namely: the benefits of participating in smoking cessation counseling, integration of services and strategies to increase the utilization of smoking cessation clinics.

\section{Benefits of participating in smoking cessation counseling}

Information about the benefits of smoking cessation counseling was obtained from two patients who have successfully stopped smoking. The main benefits gained by patients were the provision of information about tips on quitting smoking and health improvement after quitting smoking. Counseling at the clinic can lead to the intention of patients to stop smoking. In addition, an informant who has stopped smoking revealed that the smoking cessation counseling has supported his intention in quitting smoking.

"So, since I accessed the clinic, I finally reduced cigarettes, and now I rarely get sick. In the past every 2 days and 3 days I got...colds, inflammation, tightness" (I12, patient who was active smoker)

"When I was counseled at the clinic, I was told not to stop immediately, because I had tried to stop before... and my body all feverish. So since it was recommended to stop gradually, I finally stopped smoking and I feel really good" (I14, patient who has stopped smoking)

".....I have had the intention to stop since before referred to the clinic.... but cannot stop smoking... still want to stop though. Now I am counseled in the clinic as a support for me to stop..." (I13, patient who has stopped smoking)

Based on the above statement, counseling at the smoking cessation clinic requires a number of counseling sessions. An informant met again with their counselors after experiencing health problems due to immediate total smoking cessation. The advice given by the counselor addressed the concerns experienced by patients. The results of our study are similar to a study in Yogyakarta which found that smoking cessation clinics provide benefits to the health of employees both physically, mentally and socially. Employees do not easily fall sick and only experience coughs and colds. With regards to mental health, employees are not easily stressed, irritable and frustrated. ${ }^{\text {? }}$

\section{Service Integration}

The main strategy carried out by PHC-1 North Denpasar to improve the utilization of smoking cessation clinic was by recruiting patients through 
Tabel 1 Characteristics of informants

\begin{tabular}{|c|c|c|c|c|c|c|c|}
\hline No. & $\begin{array}{l}\text { Informants } \\
\text { code }\end{array}$ & Gender & $\begin{array}{c}\text { Age } \\
\text { (years) }\end{array}$ & Education & Employment & $\begin{array}{c}\text { Smoking } \\
\text { status }\end{array}$ & Sources of informants \\
\hline 1 & I1 & M & 57 & Diploma & Private employee & Active & Polyclinic referral \\
\hline 2 & $\mathrm{I} 2$ & M & 67 & Diploma & Private employee & Active & Polyclinic referral \\
\hline 3 & I3 & M & 50 & Junior high & Private employee & Stopped & Polyclinic referral \\
\hline 4 & $\mathrm{I} 4$ & M & 46 & Senior high & Private employee & Active & Polyclinic referral \\
\hline 5 & I5 & M & 19 & Senior high & Student & Active & Polyclinic referral \\
\hline 6 & I6 & M & 70 & Elementary & Private employee & Stopped & Polyclinic referral \\
\hline 7 & I7 & M & 45 & Junior high & Private employee & Active & Polyclinic referral \\
\hline 8 & I8 & M & 57 & Junior high & Private employee & Active & Polyclinic referral \\
\hline 9 & I9 & M & 53 & Junior high & Private employee & Active & Polyclinic referral \\
\hline 10 & $\mathrm{I} 10$ & M & 48 & Senior high & Private employee & Active & Polyclinic referral \\
\hline 11 & I11 & M & 23 & Bachelor & University student & Stopped & Polyclinic referral \\
\hline 12 & $\mathrm{I} 12$ & M & 48 & Senior high & Private employee & Active & Polyclinic referral \\
\hline 13 & I13 & M & 45 & Senior high & Private employee & Stopped & Polyclinic referral \\
\hline 14 & I14 & M & 52 & Senior high & Private employee & Stopped & Polyclinic referral \\
\hline 15 & I15 & $\mathrm{F}$ & 53 & Diploma & Counselor & NA & NA \\
\hline 16 & $\mathrm{I} 16$ & $\mathrm{~F}$ & 53 & Master & Head of PHC & NA & NA \\
\hline
\end{tabular}

Note: Gender: $\mathrm{M}=$ male, $\mathrm{F}=$ female

referrals from polyclinic. This is in accordance with the procedures of the $\mathrm{PHC}$ which stipulate that general polyclinic must refer patients to the smoking cessation clinic. The patients will be asked to fill out a Personal Health Record Book or Buku Rekam Kesehatan Pribadi (BRKP) that has been stamped by a doctor in the general polyclinic.

"The services at the PHC are all the same, they have to go through the counters first and then refer them based on their visit purposes. With regards to smoking cessation clinic, this has not been considered necessary by the community, so we made a variation that involved screening every patient who smoked at the counter and the general polyclinic. Then, we counseled at the smoking cessation clinic by using a Personal Health Record Book which had been stamped by a doctor in the general polyclinic" (I15, smoking cessation counselor)

"In order to increase the number of patients utilizing the services, we screen them at the general polyclinic because those who come here don't know what the benefits of stopping smoking are" (I16, head of PHC)

The information above shows that smoking cessation clinic at PHC-1 North Denpasar services only depend on patients referred by general polyclinic. This is in accordance with the standard operational procedure (SOP) in PHC-1 North Denpasar where the smoking cessation clinic services are divided into two streams including referred and voluntary counseling patients. This is similar with a smoking cessation clinic at a PHC in Yogyakarta where referrals to the clinic were from general polyclinic, mother and child health, elderly and dental clinics, while voluntary patients are those who come to the PHC only for counseling to stop smoking. ${ }^{8}$

Information from the service provider regarding referral from general polyclinic is consistent with the reasons of utilizing smoking cessation clinic from patients. At the time of examination at the general polyclinic, the doctor would enquire about the smoking status of the patient, and if he had a history of smoking he would be referred to the clinic for counseling to stop smoking.

"...when I went to the health center I wanted to check because of a cough, I was examined by a doctor. After that I was told that there was a clinic to stop smoking." (I4, patient who was active smoker)

"... when I checked at the doctor, I was asked whether I was smoking ... I answered that I was a smoker but rarely smoked ... then I was asked to go to the smoking cessation clinic" (I11, patient who has stopped smoking)

Furthermore, before being referred by the polyclinic doctor, the informant did not know about the existence of smoking cessation clinic and its benefits. 
"When I got a cold it wouldn't go away so I was suggested to go to the smoking cessation clinic but before that I didn't know what the clinic was...and for what" (I7, patient who was active smoker)

"Um ... I didn't know what the clinic was for, I only found out about it because of this headache ... I learnt it was because of smoking so they told me to cut back" (I8, patient who was active smoker)

"I only found out about it at that time. There was no information beforehand" (I6, patient who has stopped smoking)

This study indicated that the recruitment and promotion carried out by PHC-1 North Denpasar remains limited with passively waiting for referrals from other clinics at the PHC-1 North Denpasar and not recruiting patients from elsewhere. This is supported by the fact that none of the informants knew about the existence of smoking cessation clinic before being referred. According to the principle of social marketing that in order to achieve the target of the program, the company must focus on communicating with customers about the products being delivered. ${ }^{9}$ This theory recommends the need for companies/providers to promote their services or products. The implication of this theory on the development of smoking cessation clinic in PHC-1 North Denpasar is the need for increased service promotion to the public. A study in Yogyakarta shows that one of the enabling factors that influence the intention to utilize smoking cessation clinics is the availability of health promotion media and promotion of the services. ${ }^{3}$

\section{Strategies to increase the utilization of smoking cessation clinic}

The theme related to strategies to improve the utilization of smoking cessation clinic is the need to improve facilities and variations of services with a combination of increasing knowledge, providing treatment and promotion. Each of these efforts is described below.

The lack of services and supporting facilities in the smoking cessation clinic at PHC-1 North Denpasar impairs the quality of services provided to patients. Some informants said that the services and supporting facilities available in the clinic remain limited to smoking cessation counseling and smoker lacer (a means for checking nicotine levels through breathing). This current situation implies the need of efforts to improve the quality of smoking cessation clinic services.

"At the smoking cessation clinic, it seems that services and supporting facilities are lacking, maybe because they don't have enough budget. It would be good if they can add to the budget so that the service improves" (I2, patient who was active smoker)

One patient and the head of PHC added that services at the smoking cessation clinic only focus on providing information about the tobacco toxicity, the danger, diseases caused by smoking and testing of nicotine levels.

"Services provided are counseling about the risks, dangers and consequences of smoking. Then I was asked to suck or blow in a device to find out the body's nicotine levels" (I1, patient who was active smoker)

"After that the patient is given a CO level test... if the results are high, we inform what the risks are" (I16, head of PHC)

"We only provide counseling rather than treatment, and we only provide counseling services for those who want to quit smoking" (I16, head of PHC)

The long waiting time at the general polyclinic can deter patients from accessing the smoking cessation clinic services. Some informants revealed that the waiting time at the general polyclinic was very long, with a patient can wait up to two hours before receiving smoking cessation services. This perceived as a slow service provision and causes boredom among patients.

"Services at the smoking cessation clinic are quick and easy, but at the general polyclinic it will take about two hours to get treatment" (I10, patient who was active smoker)

In addition to waiting time at general polyclinic, some informants stated that the lack of counselors in the smoking cessation clinic was one of the reasons for the long waiting time in the clinic.

"There is a need for additional counselors so that they do not become tired of waiting" (I8, patient who was active smoker)

"They need to employ more staff because there is a high turnover and the staff have multitasks" (I10, patient who was active smoker)

Counselor and the head of PHC also proposed the addition of counselors and other health workers who only focus on services in the smoking cessation clinic to expedite the counseling process.

"Actually, it is necessary to add the number of counselors so that they focus for providing 
counseling and always available at the smoking cessation clinic.... I also have to do other tasks when there are no clients at the clinic" (I15, smoking cessation counselor)

"We need an increase in human resources because one counselor has resigned. So we need another trained counselor. Our current counselor also have some other tasks to do. Yes ... if there are additional counselors, it will be better" (I16, head of PHC)

Similar issue was identified in Purwakarta where the smoking cessation counselor had multiple responsibilities. The main tasks and functions of staff at the smoking cessation clinic were unclear and relied only on one person. This impacts upon smoking cessation clinic service provision. ${ }^{10}$

In addition, smoking cessation clinics should have longer opening hours in order to fit the patient's schedule. Most of the informants explained that the clinic schedule should be more flexible and in accordance with their schedule, because of the clash with working hours.

"Yes ... they should be increased. Now only until 12 o'clock. It should be open up to 2 or 3 oclock" (I12, patient who was active smoker)

"The service hours can be increased so that it is open up to 4 o'clock, according to people's working hours. The sign out front says open from $8-12$, then what do they do the rest of the time?" (I10, patient who was active smoker)

The informants' statements implied that clinic opening hours need to be adjusted to the needs of patients as the service users. However, this might be contrary to the limited opening hours of the PHC and the available rules. According to the health providers, this is not yet possible considering the smoking cessation service hours are adjusted to the working hours of the health center.

One of the basic requirements of quality health services is availability, therefore it is necessary to adjust the clinic opening hours with the schedule of patients. The current inappropriate opening hours of smoking cessation clinic might lead to the low uptake of the services.

At the smoking cessation clinic patients mainly provided with counseling and examination of nicotine levels in the body. Services available could be modified to involve a combination between counseling and pharmacotherapy in the form of varenicline to increase smoking cessation:

"If there are drugs or sweets that can reduce cigarette addiction that would be great. At least to reduce smoking" (I2, patient who was active smoker)

"It's not enough to get counseling, there must be other methods. For example, other methods such as provision of medicine so that it doesn't take a long time to stop smoking" (I3, patient who has stopped smoking)

"Don't just check the nicotine level, maybe check the blood...check urine to increase people's interest" (I12, patient who was active smoker)

In addition, $\mathrm{PHC}$ staff has proposed to the health office in a meeting about giving medicines to stop smoking.

"In 2015/2016 there was a discourse that medicine would be prepared, but the medicine was expensive. Then even with medicine, if the patient does not routinely undergo counseling, the attempt to stop smoking could fail... while the medication is expensive. In addition, health providers at the PHC have been trained in facilitating smoking cessation using the hypnotherapy method. Well, in my opinion it's one of the methods that makes sense, because it doesn't cost high" (I16, head of PHC).

The above statements show that patients need a variety of services such as a combination of pharmacotherapy and counseling methods. A study in Canada showed that improving quality in helping to quit smoking will achieve maximum results when a combination of behavioral support and medication is applied, compared to the provision of brief advice or support only. ${ }^{11}$ The supporting theory of the results of this study is the SERVQUAL (service quality) model, particularly the assurance (guarantee) dimension, which emphasizes that providers are expected to be able to guarantee their services so that patient satisfaction can be achieved.

Some informants suggested that the promotion of the smoking cessation services can be carried out in the form of education on the dangers of smoking in schools so that students obtain this information early.

"Yes, early education is better in schools, if there is a prevention particularly facility for checking... it would be good for the next generation" (I10, patient who was active smoker)

"It is very important to carry out an education in schools, not only senior high schools but also to junior high schools. The problem is that in junior high school kids start to be trendy and follow their peers" (I5, patient who was active smoker) 
Health providers explained that they had collaborated to carry out promotion in schools, especially with the student support teachers.

"Actually, we collaborate for promoting the smoking cessation services, especially with the student support teachers in schools" (I15, smoking cessation counselor)

"So the one who conducted smoking cessation promotion is the counselor. The promotion is held every year in the integrated health service, community groups and schools" (I16, head of $\mathrm{PHC})$

A study in Purwakarta also showed that the lack of promotion resulted in the lack of public awareness about smoking cessation clinic services. Promotion can be carried out, for example, during local community meetings or other activities in the village. ${ }^{10}$

To increase the utilization of smoking cessation clinic, informants suggested that the PHC-1 North Denpasar should actively promote the smoking cessation services to the wider community such as through the Bali free talk podium. This podium is a routine activity organized by the Government of Bali Province so that people can express their aspirations, plans, suggestions and criticisms of government programs. ${ }^{12}$

"...information about smoking cessation clinic services is important to be provided during the Bali free talk podium. So, there could be a chance for the doctor to talk and to provide information about the smoking cessation clinic" (I2, patient who was active smoker)

The limitation of this study is that most informants utilized the smoking cessation services in PHC-1 North Denpasar only once, therefore information about the roles of the clinic in the process of smoking cessation could not be comprehensively explained. In addition, there was a limited variation of the informants, especially patients who had successfully stopped smoking.

\section{CONCLUSION}

This study showed that the utilization of the smoking cessation clinic in the study site remains very low. Some of the causes identified were the strategy of patient recruitment based only on referrals from general polyclinic, the lack of supporting facilities, services that only focused on giving information, long waiting times and lack of promotion of the clinic. Suggestions from the informants to overcome this problem included improving supporting facilities, provision of varied services by combining information and medication, and promotion of the clinic in existing sub-systems such as schools and community forums.

\section{ACKNOWLEDGEMENT}

We would like to thank all informants who have participated in this study, including the smoking cessation counselor and the Head of PHC-1 North Denpasar who have also supported the implementation of this study.

\section{REFERENCES}

1. Sajinadiyasa IGK, Bagiada IM, Rai IBN. Prevalensi dan risiko merokok terhadap penyakit paru di Poliklinik Paru Rumah Sakit Umum Pusat Sanglah Denpasar [Prevalence and risk of smoking to lung diseases at Pulmonary Diseases Polyclinic Sanglah General Hospital Denpasar]. Jurnal Penyakit Dalam. 2010; 11(2): 91-5.

2. Ministry of Health of Indonesia. Riset Kesehatan Dasar [The 2018 Indonesia Basic Health Research]. Jakarta; 2018.

3. Widiastuti W. Analisis faktor-faktor yang mempengaruhi niat pasien Poliklinik Penyakit Dalam untuk memanfaatkan klinik berhenti merokok di Rumah Sakit Umum Daerah Kota Yogyakarta (Tesis) [Analysis of factors associated with patients' intention to utilize smoking cessation clinic at the Yogyakarta General Hospital (Thesis)]. 2013. Universitas Gajah Mada. Yogyakarta.

4. PHC-1 North Denpasar. Laporan kunjungan klinik berhenti merokok [Report on the visits to smoking cessation clinic]. 2016. Unpublished.

5. Jirojwong S, Liamputtong P. Population health, communities and health promotion. Melbourne: Oxford University Press; 2009.

6. Bungin B. Analisis data penelitian kualitatif [Data analysis of a qualitative study]. Jakarta: PT. Rajagrafindo Persada; 2010. p. 98.

7. Trisnowati H, Hardiyanti DA. Klinik konseling berhenti merokok dan kesehatan kerja pegawai (Studi pada Puskesmas Jetis Yogyakarta) (Proceeding) [Smoking cessation clinic and employee's health (A study at Jetis PHC Yogyakarta) (Proceeding)]. 2016 The $3^{\text {rd }}$ Indonesian Conference on Tobacco or Health, 26-30 November 2016.

8. Smoking Cessation Clinic. Memulai klinik berhenti merokok dari puskesmas [Starting the smoking cessation clinic from the public health center]. 2012. Available from: http://www.masyarakatsehat.net/index.php/agendakegiatan/87-lingkungan/178-memulai-klinik-berhentimerokok-dari-PHC. Accessed on 11 January 2018.

9. Valerie A, Zeithaml MJB. Service Marketing. 2000. McGraw Hill Companies Inc. Singapore.

10. Susanti D. Evaluasi hambatan penyelenggaraan klinik berhenti merokok di Kabupaten Purwakarta [Evaluation on the barriers to the implementation of smoking cessation clinic in Purwakarta District]. 2010.

11. Stead L, Koilpillai P, Fanshawe T, Lancaster T. Combined pharmacotherapy and behavioural interventions for smoking cessation. Cochrane Database of Systematic Reviews. 2016; (3).

12. Rhismawati NL. Gubernur Bali minta "podium bali bebas bicara" dilanjutkan [The Governor of Bali Province asked "podium of Bali free to speak" to be continued]. ANTARA News Bali. 7 Januari 2018

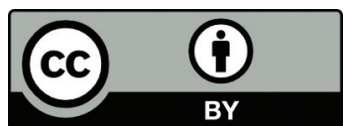

This work is licensed under a Creative Commons Attribution 